\title{
Managing idiopathic short stature: role of somatropin (rDNA origin) for injection
}

\author{
This article was published in the following Dove Press journal: \\ Biologics: Targets \& Therapy \\ 4 June 2010 \\ Number of times this article has been viewed
}

\author{
J Paul Frindik' \\ Stephen F Kemp' \\ 'University of Arkansas for Medical \\ Sciences and Arkansas Children's \\ Hospital, AR, USA
}

\begin{abstract}
Idiopathic short stature (ISS) is a term that describes short stature in children who do not have growth hormone $(\mathrm{GH})$ deficiency and in whom the etiology of the short stature is not identified. Between 1985 and 2000, more than 40 studies were published regarding GH therapy for ISS. Only 12 of these had data to adult height, of which only 4 were controlled studies. A subsequent placebo-controlled study that followed subjects to adult height indicated that there was a gain of 3.7-7.5 cm in height with GH treatment. In 2003, the US Federal Drug Administration (FDA) approved GH for treatment of short stature. Even before FDA approval, patients with ISS made up about $20 \%$ of patients in GH databases, which is largely unchanged since FDA approval. There remains some controversy as to whether GH should be used to treat ISS. This controversy centers on the fact that there has been no definitive demonstration that short stature results in a disadvantage or problems with psychological adjustment, and thus, no demonstration that GH therapy results in improvement in quality of life.
\end{abstract}

Keywords: idiopathic short stature, ISS, growth hormone therapy, somatotropin, somatropin, insulin-like growth factor I, IGF-1

\section{Introduction}

Idiopathic short stature (ISS) is one of several terms that have been used to describe short stature in children who do not have growth hormone $(\mathrm{GH})$ deficiency and in whom the etiology of their condition is not understood. Other terms that have been used in the past to describe these children, some overlapping those that describe ISS, include familial short stature, normal variant short stature, idiopathic growth failure, non-GH-deficient short stature, and nonendocrine short stature. Some patients with ISS have been diagnosed with GH neurosecretory dysfunction (ie, low spontaneous GH secretion) as a means of justifying GH therapy. All recognizable causes of short stature (ie, intrauterine growth retardation, genetic or syndromic causes of short stature, and psychosocial deprivation) should be ruled out before a diagnosis of ISS is made. ${ }^{1}$ As a group, children with ISS do not achieve their adult height predictions, and many have adult heights that are quite short. ${ }^{2,3}$ As more is understood about the causes of short stature, it is hoped that many of these children may eventually have a more definitive diagnosis. An example of this situation is a recent report of a child with ISS who was ultimately diagnosed with a deletion in exon 5 of the Short Homeobox X (SHOX) gene. ${ }^{4}$

\section{A short history of $\mathrm{GH}$ therapy}

The first report on GH therapy for growth hormone deficiency (GHD) was produced in $1958 .{ }^{5}$ The first GH preparations (somatotropin) used therapeutically were derived 
from human cadaver pituitaries. In the United States, humanderived growth hormone was produced and distributed by the National Institute of Health's (NIH) National Pituitary Agency. The preparation was in short supply, resulting in lower than ideal dosing and frequent drug holidays. Potential recipients were required to participate in a research protocol and, in order to ration the cadaveric $\mathrm{GH}$, the diagnosis of $\mathrm{GH}$-deficiency required that the patient have a peak GH level in response to provocative stimuli below a certain level. This requirement gradually increased in response to a better supply of cadaveric $\mathrm{GH}$, starting at $5 \mathrm{ng} / \mathrm{mL}$, then $7 \mathrm{ng} / \mathrm{mL}$, and finally $10 \mathrm{ng} / \mathrm{mL}$ in the early 1980s. In 1985, this preparation was linked to a risk for Creuzfeldt-Jacob disease, ${ }^{6,7}$ and its use was discontinued. In 1979, GH was produced in large quantities by expressing the human GH gene in Escherichia coli. ${ }^{8}$ In 1985, Genentech Inc. (San Francisco, CA, USA) was approved by the Food and Drug Administration (FDA) to market recombinant human growth hormone (rhGH), ${ }^{9}$ which was identical to human growth hormone, with the addition of a methionine as a necessary start signal for the bacteria to initiate protein synthesis. Use of methionyl GH did result in antibody production, but this was rarely associated with growth attenuation. ${ }^{10}$ Present-day commercial preparations (somatropin) all have the identical 191-amino acid sequence of native human pituitary hormone. ${ }^{11}$

Initially, GH was injected intramuscularly. But, in the mid-1980s (about the time of introduction of $\mathrm{rhGH}$ ), it was shown to be as effective if given as a subcutaneous injection, ${ }^{12}$ which is the practice today. Early in its use, GH was given twice weekly, but this was increased to three times weekly when the higher frequency was shown to result in an increased growth response. ${ }^{13}$ At about the time of the transition from cadaveric $\mathrm{GH}$ to $\mathrm{rhGH}$, it was demonstrated that daily injections ( 6 or 7 per week) yielded an even better growth response than the three times per week schedule, ${ }^{14-17}$ and daily administration is commonly used today.

\section{GH treatment of ISS}

During the time of cadaveric growth hormone, usage was limited to GHD because of the scarcity of supply. However, even before the advent of rhGH, there was interest in investigating whether treatment of other conditions associated with short stature would increase adult stature. Between 1964 and 1971, there were a number of small studies that examined the treatment of non-GH-deficient short stature with GH. ${ }^{18}$ In 1964, the National Institute of Child Health and Human Development (NICHD), a branch of the NIH, sponsored an international conference that recommended analysis of
$\mathrm{GH}$ treatment in non-GH-deficient conditions. In 1983 , a conference sponsored by the NICHD, entitled International Conference on Uses and Abuses of Growth Hormone, brought up this topic, resulting in the following statement: “... there is an urgent need for therapeutic trials to determine the effect of growth hormone in short children who do not have a growth hormone deficiency". In 1987, a FDA committee recommended a placebo-controlled study of GH treatment for ISS that would follow subjects to adult height.

A placebo-controlled trial of treatment of children with ISS in collaboration with Eli Lilly (Indianapolis, IN, USA) and the NIH was carried out between 1988 and 2001. Data from this trial were presented to the NIH. In July 2003, the FDA approved the use of GH in children with ISS. They defined children with ISS as those having a height that was greater than 2.25 standard deviations (SD) below the mean (one of the inclusion criteria of the Eli Lilly/NIH collaborative trial), open epiphyses, a growth velocity that makes it unlikely that the child's adult height will be in the normal range (ie, within $2 \mathrm{SD}$ of the mean), and a diagnostic evaluation that has excluded other causes associated with short stature, which would better be managed by observation or treatment by other means. One of the concerns has been the possibility of misdiagnosing and treating children for ISS who actually have constitutional delay in growth and maturation (CD), particularly if the child's bone age is delayed. Certainly, there are such patients. However, if the FDA guidelines are adhered to, a child who is more than 2.25 SD below the mean, and has a predicted adult height that is more than 2 SD below the mean, is probably more appropriately considered to have ISS than to be classified as having CD. There is evidence that adult height tends to be overpredicted, particularly in boys. ${ }^{19}$

According to a recent survey of pediatric endocrinologists, there is still not agreement as to whether or when children with ISS should be treated. ${ }^{20}$ Most of the respondents to the survey agreed that there was a need for indication. Respondents were asked about the cut-off height of $-2.25 \mathrm{SD}$. $71 \%$ responded that it was appropriate, $21 \%$ thought it should be set higher, and $8 \%$ thought it should be set lower. When asked about factors contributing to willingness to prescribe (78\% selected more than one response), 53\% selected "patient expression of understanding potential risk and benefits", 32\% selected "family insistence", 14\% selected "family's desire to pay", and $7 \%$ selected "male gender". The case against treatment is that there is not a convincing body of evidence to indicate that short stature is actually a real problem, or that treatment (or taller stature) leads to any psychological benefit. ${ }^{21}$ Treatment of 
GHD is justified because it represents replacement of a missing hormone. On the side of treating ISS patients, Saenger ${ }^{22}$ argues that the diagnosis of GHD is very difficult to make with certainty, and in the absence of meaning psychological outcome data, we should follow the recommendation of the American Academy of Pediatrics, ${ }^{23}$ which recommends treatment of very short children whose ability to participate in basic activities of daily living is limited because of their short stature. One of the fears after ISS became an FDA-approved indication was that there would be a change in the paradigm determining which short children are treated (resulting in the treatment of many more children who were not as short). We compared demographic data in the National Cooperative Growth Study (NCGS) of children who were treated for ISS before 2003 and from 2003-2006 (ie, after FDA approval). ${ }^{24}$ Although no major changes were seen, there was a very small decrease in the severity of the growth retardation at entry, and a slight increase in the treatment doses. Mean height velocities during treatment were the same before and after FDA approval.

\section{Efficacy of GH treatment in ISS}

Children with ISS who are treated with GH are as short at the beginning of GH therapy as children with chronic renal insufficiency, Turner syndrome, or those who are born small for gestational age: that is, their heights before treatment average from $-2.6 \mathrm{SD}$ to $-2.9 \mathrm{SD} .{ }^{25-29}$ In this group of children, insulin-like growth factor-1 (IGF-1) levels are often normal. However, approximately $25 \%$ of them are low, suggesting that some children in this group may have GH-insensitivity. Many of the published studies of GH therapy in children with ISS have involved small sample sizes and did not have control groups ( 28 uncontrolled vs 10 with a control group). ${ }^{18}$ Even with these limitations, a meta-analysis of these studies suggested that the overall height gain may have been from -3.0 to $-1.5 \mathrm{SD}$ with $\mathrm{GH}$ therapy, ${ }^{18}$ which represents a height increase of 4-6 cm. In studies with a control group, it appeared that the control group also had an increase in height (consistent with a previous report of spontaneous growth in children with ISS), ${ }^{30}$ but the treated group exceeded the control group by approximately $0.78 \mathrm{SD}$. Subsequent to this meta-analysis, results of a placebo-controlled study on the effect of GH therapy on adult height in peripubertal children with ISS demonstrated a height increase of 3.7-5.0 cm with $\mathrm{GH}$ therapy, despite a low dose of GH $(0.22 \mathrm{mg} / \mathrm{kg} /$ week $)$ and an injection schedule of three times per week. ${ }^{31} \mathrm{~A}$ second study evaluating two treatment protocols demonstrated a dose effect with a dosage of $0.37 \mathrm{mg} / \mathrm{kg} /$ week resulting in an increase in adult height of $7.2 \mathrm{~cm}$ compared with $5.4 \mathrm{~cm}$ in the group receiving only $0.24 \mathrm{mg} / \mathrm{kg} /$ week. $^{32} \mathrm{~A}$ recent report of comparison of two doses $(0.23$ and $0.47 \mathrm{mg} / \mathrm{kg}$ / week) of $\mathrm{GH}$ and an untreated population in a group of 177 children, most of whom had ISS, showed that there was a dose-dependent increase in adult height, ${ }^{33}$ with a gain of about 1.5 SD in the group treated with the higher dose. An evaluation of data from children with ISS treated with GH, taken from a large $\mathrm{GH}$ database, showed that GH treatment resulted in an increase in height from -3.0 to $-1.2 \mathrm{SD}$ over the course of 7 years. ${ }^{26}$ Factors that tend to predict a positive response to $\mathrm{GH}$ treatment include $\mathrm{GH}$ dose, degree of height deficit compared to parents' heights, young age, and first year height velocity. ${ }^{1,34}$

\section{Safety of GH treatment in ISS}

An evaluation by Quigley et $\mathrm{al}^{35}$ of safety data from the controlled trial of GH therapy of children with ISS $^{31}$ and the subsequent dose-response study, ${ }^{32}$ as well as an evaluation of more than 8,000 ISS patients followed in a large postmarketing database for children treated with $\mathrm{GH},{ }^{26}$ have shown that there are no safety issues in GH therapy different from those seen with treatment of GH deficiency.

\section{Psychosocial effect of treating ISS}

It is assumed that short stature is associated with disadvantages and problems of psychological adjustment. Anecdotal reports include teasing, treating children in relation to their height rather than their age (juvenilization), and academic underachievement. ${ }^{36}$ Some studies seem to confirm these notions, ${ }^{37-40}$ while others have failed to demonstrate any disadvantage to short stature, including any problem with psychological adjustment. ${ }^{41-44}$ In fact, Kranzler et $\mathrm{al}^{45}$ evaluated 90 children who were sent to a stature clinic, and determined that they had normal psychological function without externalizing behavior problems, attention problems, or poor social skills, as had been previous reported. ${ }^{39,46,47}$ Sandberg ${ }^{48}$ reported that juvenilization does occur, but short stature is not associated with any social advantage. Balen et $\mathrm{al}^{49}$ have suggested that patients referred for ISS seem to be more at risk for psychological problems than those who are not referred. Further, they indicate that, in addition to stature, there are other risk factors for psychological difficulty, including being juvenilized, being a boy, having low intelligence, having a younger but taller sibling, and being part of a family with low socioeconomic status. In light of this controversy, it is not surprising that it has been difficult to demonstrate that treatment of ISS (and short stature 
in general) improves the quality of life of the individual. Many who treat children with ISS believe that by increasing adult height they are improving quality of life. ${ }^{50}$ However, there is little objective data to support this notion. ${ }^{51}$ In fact, the idea that short stature is a problem that can be addressed by GH treatment has been recently challenged in the popular press. ${ }^{52}$ Recent reviews of available instruments for evaluating quality of life in children with GHD or ISS suggest that it should be possible to do the studies that could help answer whether treatment with $\mathrm{GH}$ has a positive or negative effect on quality of life. ${ }^{53,54}$ The question of efficacy of GH treatment is particularly relevant because of the expense of GH therapy: perhaps as much as US\$52,634 per inch. ${ }^{55}$ In spite of the difficulty of demonstrating that an increase in height also results in increased quality of life, children with ISS have been treated with GH since at least the inception of the NCGS in 1985, accounting for approximately $20 \%$ of those patients treated with GH. ${ }^{56}$ Savage ${ }^{57}$ has suggested that 1) if growth hormone therapy is restricted to a height threshold of -2.5 or $-3.0 \mathrm{SD}$, and 2) if treatment would be limited to those children with slow height velocity, there might be fewer children who would experience a benefit in terms of taller stature than would have been attained without treatment. Further, Savage indicates that continued treatment should depend upon an increase in height velocity of at least $2 \mathrm{~cm} /$ year; if such an increase in height velocity does not occur, GH therapy should be discontinued.

\section{Evidence that some ISS cases may be caused by genetic mutations in GH-IGF-I axis}

The GH receptor gene is the first gene that was associated with growth failure, possibly including ISS. It is well recognized that mutations in the GH receptor are responsible for complete GH-resistance (also known as GH-insensitivity syndrome), in which it has been possible to identify about $70 \%-80 \%$ of patients with low levels of GH binding protein (GHBP), which is the extracellular portion of the $\mathrm{GH}$ receptor. About 30 distinct mutations have been described. ${ }^{58}$ Point mutations of the intracellular domain have also been described. However, most of these have also been found in subjects with normal height, and have been considered to be polymorphisms. ${ }^{59-61}$ In order to determine whether partial GH-insensitivity was responsible for growth failure in children with ISS, data were analyzed from 773 children who were being treated with $\mathrm{GH}$ and were enrolled in a postmarketing surveillance project, the NCGS. ${ }^{62}$ Patients enrolled in this study had their levels of insuline-like growth factor 1 (IGF-1) and GHBP determined. In addition, these patients had been evaluated for GH-deficiency by their response to provocative stimuli. Patients with a GH response of more than $10 \mathrm{ng} / \mathrm{mL}$ were classified as having ISS. Children with ISS had GHBP levels more than 2 SD below the normal control patients, IGF-1 levels lower than controls (108-120 $\mu \mathrm{g} / \mathrm{L}$ vs $217-308 \mu \mathrm{g} / \mathrm{L})$, but higher than in patients with $\mathrm{GH}-$ deficiency (84-99 $\mu \mathrm{g} / \mathrm{L})$, and mean 12 hour GH concentrations similar to controls $(2.2 \mu \mathrm{g} / \mathrm{L}$ vs $2.1-2.7 \mu \mathrm{g} / \mathrm{L})$, but higher than in patients with GH-deficiency $(1.2-1.4 \mu \mathrm{g} / \mathrm{L})$. A subset of 14 of these patients (height more than 2.5 SD below mean, normal GH secretion, IGF-1 levels more than 2 SD below the mean, and serum concentrations of GHBP more than $2 \mathrm{SD}$ below the mean) were further studied. ${ }^{63}$ Of the 14 patients, four had mutations in the $\mathrm{GH}$ receptor (none of the 24 control subjects had mutations). One of these patients was a compound heterozygote with respect to the $\mathrm{GH}$ receptor. Due to these findings, it has been suggested that partial GH-insensitivity may be a cause of growth failure in some children with ISS. It may be possible that they would respond to $\mathrm{GH}$ at higher doses, or it may be that these children should be treated with IGF-1 instead of GH. Certainly, the case can be made that mutations in the $\mathrm{GH}$ receptor could explain ISS in some of the patients. In a recent study, a pool of 188 patients with ISS were analyzed for mutations in the $\mathrm{GH}$ receptor in order to determine if finding these mutations would predict response to therapy. Mutations were present in fewer than $5 \%$ of the patients, and discovery of single-gene defects did not predict treatment response. ${ }^{64}$

A second area of inquiry has been the SHOX gene. This gene resides on the distal ends of the short arms of chromosomes $\mathrm{X}$ and $\mathrm{Y}$ (in the pseudoautosomal region). ${ }^{65}$ It appears that two functional copies of this gene are required for attainment of normal stature. Thus, absence of this gene from the loss of one or part of one $\mathrm{X}$ chromosome is associated with the short stature of Turner syndrome. Likewise, a mutation in one of the SHOX genes has been shown to be the cause of Leri-Weill syndrome, also known as dyschondrosteosis. ${ }^{66,67}$ Screening of ISS patients for abnormalities in the SHOX gene has been a logical step. Rao ${ }^{65}$ reported one patient with a functionally significant mutation in the SHOX gene out of 91 patients with ISS screened. Ogata ${ }^{68}$ expanded the screen to include 400 patients with ISS, and found the aforementioned patient, along with 3 others with SHOX gene mutations. In an analysis of 68 patients with ISS, one female patient was identified who had a normal karyotype but a deletion of one SHOX allele. ${ }^{69}$ 
Other gene defects that have recently been discovered to result in growth failure include defects in the growth hormone receptor's intracellular signaling, in particular, signal transducer and activator of transcription $5 \mathrm{~b}$ (STAT5b), ${ }^{70}$ and a defect in the acid-labile subunit (ALS) of the circulating IGF-1 complex. ${ }^{71}$ STAT5b-deficiency results in a phenotype of GH-insensitivity and immunodeficiency, while ALSdeficient patients have rather subtle growth failure, with height tracking at about or just below the 3 rd centile. Neither of these defects has been identified in patients diagnosed as having ISS, ${ }^{64,72}$ perhaps in part because they represent very rare disorders. Also, it has been pointed out that the phenotype of STAT5b-deficiency is that of severe GH-resistance, and it is not likely to be mistaken for ISS. ${ }^{64}$ Perhaps the reason that ALS-deficiency has not been identified in a population of ISS patients is because the growth failure associated with it is too subtle for the affected child to be labeled as having ISS.

It appears that mutations in the $\mathrm{GH}$ receptor and the SHOX gene account for between $1 \%$ and $5 \%$ of the cases of growth failure that are designated ISS. As more patients with ISS are investigated, it is likely that additional genes responsible for growth failure will be discovered. As we recognize various causes for ISS, the pool of children with this designation should continue to decrease.

\section{IGF-I treatment of ISS}

In August and December of 2005, mecasermin IGF-1 (Increlex $^{\circledR}$, Tercica Inc, Brisbane, CA, USA) and mecasermin rinfabate IGFBP-3 (Insulin-like growth factor binding protein 3) (Iplex ${ }^{\circledR}$, Insmed, Glen Allen, VA, USA) received approval from the FDA for the treatment of children with severe primary IGF-deficiency or children with a GH gene deletion who have developed neutralizing antibodies to $\mathrm{GH}$. Mecasermin rinfabate is no longer available for treating conditions with short stature because of a legal agreement. These compounds have been shown to be effective in treating cases of GH-insensitivity ${ }^{73,74}$ and IGF gene deletion. ${ }^{75}$ In spite of ISS being an off-label use, there was a poster presentation of data from the Increlex Growth Forum Database Registry at the 2007 meeting of the Endocrine Society, ${ }^{76}$ which showed that $17 \%$ of enrolled patients were identified as having ISS. Rosenbloom ${ }^{77}$ has assented that "partial GH-insensitivity" is not evidencebased, but represents an attempt by the manufacturer to promote use of their product by a wider market than the rather small number of patients with true GH-insensitivity. ${ }^{77}$ Because of the paucity of published data regarding the treatment of ISS (or partial GH-insensitivity), the role of treatment of ISS with IGF-1 remains to be determined. ${ }^{78,79}$
Treatment of GH receptor-deficiency with IGF-1 has resulted in a number of mild to moderate adverse events. Most commonly reported adverse events have included pain at the injection site and headaches. Data from a European study indicate that these events occur during the first month of treatment and then improve ${ }^{80}$ Other adverse events that have been reported following IGF-1 therapy have included lipohypertrophy at the injection site, papilloedema related to increased intracranial hypertension, and facial nerve paralysis. ${ }^{81,82}$ With these events, symptoms resolved after interrupting treatment and re-starting with a lower dose. ${ }^{80,83}$

A second concern has been hypoglycemia, which occurred in some of the patients receiving IGF-1, but only rarely resulted in seizures. ${ }^{73,84}$ This problem was lessened by administering the IGF-1 dose with meals, and hypoglycemia was usually a problem when there was an intercurrent illness resulting in loss of appetite.

Another effect of IGF-1 therapy has been the growth of lymphoid tissue, in particular, splenic enlargement and tonsillar hypertrophy. Renal size also increased, but renal function remained normal. ${ }^{73}$ There were changes in facial appearance, with coarsening of features and an increase in hair growth, which were most noticeable during puberty. A complex of IGF-1 and IGFBP-3 appears to prolong the half-life and might counteract acute adverse events, particularly hypoglycemia associated with administration of IGF-1.

A recent report of treatment of 136 short children (presumable ISS) with IGF- ${ }^{85}$ showed that there was a statistically significantly increased growth velocity in the groups receiving 80 or $120 \mu \mathrm{g} / \mathrm{kg}$ twice daily vs a non-treated control group. However, there were significant reports of adverse events in the group: headaches $38 \%$, vomiting $25 \%$, and hypoglycemia 14\%; in fact, six subjects withdrew because of adverse events. In an accompanying editorial, Rosenbloom and Rivkees ${ }^{86}$ question whether there is adequate growth promotion to justify the apparent risks of treating with IGF-1 in this population.

\section{Other approaches to treatment of ISS LHRH agonists}

It is well-recognized that treatment of early-onset precocious puberty with luteinizing hormone-releasing hormone (LHRH) agonists such as gonadotropin-releasing hormone agonist (GnRHa) allows adult height to approach target height. ${ }^{87}$ It has been postulated that GH may hasten the 
progression of puberty, and that the addition of GnRHa treatment may permit further growth in children with ISS. Kamp et al demonstrated that the addition of GnRHa to GH therapy in children with ISS or intrauterine growth restriction resulted in an increase in predicted adult height of $8.0 \mathrm{~cm}$ in girls and $10.4 \mathrm{~cm}$ in boys. ${ }^{88} \mathrm{~A}$ prospective study comparing treatment of normal short girls with GH alone or with GH plus GnRHa suggested that while GH alone resulted in an increase in predicted adult height, the addition of GnRHa combined with GH resulted in an even greater increase in predicted adult height. ${ }^{89}$ The evaluation of two large GH registry databases,${ }^{90} \mathrm{GH}$ prediction models, ${ }^{90}$ and a recent report of lack of efficancy in increasing adult height when treatment is initiated after the age of $7-8$ years ${ }^{91}$ do not support the success of this treatment. At present, there are no universally agreed upon guidelines for the use of GnRHa with (or without) GH in children with ISS. Thus, this therapy is still considered experimental.

\section{Aromatase inhibitors}

A recent study has demonstrated a $5.9 \mathrm{~cm}$ increase in predicted adult height in boys with ISS using an inhibitor of aromatase (letrozole) without GH treatment for 24 months. ${ }^{92}$ The same group has reported a similar finding in boys with constitutional delay treated to near adult height with letrozole. ${ }^{93}$ The group receiving letrozole reached a near adult height which was $6.7 \mathrm{~cm}$ taller than those who did not. Although these reports appear quite promising, further studies carried out to adult height, with a careful evaluation of safety, are needed before this therapy can be adopted in a clinical setting. ${ }^{87}$

\section{Conclusion}

ISS describes a group of children who are very short (more than 2 SD below the mean) and who are not GH-deficient. As early as 1983, there was interest in determining whether treating these children increased their adult height. Between 1985 and 2000, there were more than 40 studies published on the treatment of ISS. Most involved small patient populations, only 12 had adult height data, and only four were controlled. A controlled study was undertaken between the NHI and Eli Lilly. Subsequently, that study demonstrated an increase in adult height from $3.7-7.5 \mathrm{~cm}$ (1.5-3 inches) with GH treatment. ${ }^{31,32}$ The FDA approved the ISS indication in July 2003. An analysis of the data from a large registry of patients receiving $\mathrm{GH}$ demonstrated a similar response to therapy and no differences in safety than for the treatment of GH-deficiency. Genetic explanations for ISS have occurred in approximately $5 \%$ of the patients evaluated, including genetic mutations of the GH-IGF-1 axis, including STAT5b mutations, SHOX gene mutations, and ALS mutations. With time, there will likely be a larger group of patients in which the etiology of their short stature is elucidated. There are few data regarding whether a psychological advantage is gained by patients with ISS treated with GH. Other approaches to treating ISS include treating with IGF-1 (alone or in combination with $\mathrm{GH}$ ), which has the added risk of adverse events, or delaying puberty with LHRH agonists or aromatase inhibitor. Both of the latter approaches are still in experimental stages.

\section{Disclosures}

The authors reports no conflicts of interest in this work.

\section{References}

1. Wit JM, Clayton PE, Rogol AD, Savage MO, Saenger PH, Cohen P. Idiopathic short stature: definition, epidemiology, and diagnostic evaluation. Growth Horm IGF Rese. 2008;18(2):89-110.

2. Buchlis JG, Irizarry L, Crotzer BC, Shine BJ, Allen L, MacGillivray $\mathrm{MH}$. Comparison of final heights of growth hormone-treated vs untreated children with idiopathic growth failure. J Clin Endocrinol Metab. 1998;83(4):1075-1079.

3. Ranke MB, Grauer ML, Kistner K, Blum WF, Wollmann HA. Spontaneous adult height in idiopathic short stature. Hormone Rese. 1996;44(4):152-157.

4. Shanske AL, Puri M, Marshall B, Saenger P. Unique deletion in exon 5 of SHOX gene in a patient wtih idiopathic short stature. Hormone Res. 1996;67(2):61-66.

5. Raben MS. Treatment of a pituitary dwarf with human growth hormone. J Clin Endocrinol Metab. 1958;18(8):901-903.

6. Frasier SD. The not-so-good old days: working with pituitary growth hormone in North America, 1956-1985. J Pediatr. 1997;131 (1 Pt 2):S1-S4.

7. Hintz RL. The prismatic case of Creutzfeldt-Jacob disease associated with primary growth hormone treatment. J Clin Endocrinol Metab. 1995;80(8):2298-2301.

8. Goeddel DV, Heyneker HL, Hozumi T, et al. Direct expression in Escherichia coli of a DNA sequence coding for human growth hormone. Nature. 1979;281(5732):544-548.

9. Flodh H. Human growth hormone produced with recombinant DNA technology: development and production. Acta Paediatr Scand Suppl. 1986;325:1-9.

10. Massa GG, Vanderschueren-Lodeweyckx M, Bouillon R. Five-year follow-up of growth hormone antibodies in growth hormone deficient children treated with recombinant human growth hormone. Clin Endocrinol (Oxf). 1993;38(2):137-142.

11. Franklin SL, Geffner ME. Growth hormone: the expansion of available products and indications. Endocrinol Metav Clin North Am. 2009;38(3):587-611.

12. Wilson DM, Baker B, Hintz RL, Rosenfeld RG. Subcutaneous versus intramuscular growth hormone therapy: growth and acute somatomedin response. Pediatrics 1985;76(3):361-364.

13. Milner RD, Russell-Fraser T, Brook CG, et al. Experience with human growth hormone in Great Britain: the report of the MRC Working Party. Clin Endocrinol (Oxf). 1979;11(1):15-38.

14. Albertsson-Wikland K, Westphal O, Westgren U. Daily subcutaneous administration of human growth hormone in growth hormone deficient children. Acta Paediatr Scand. 1986;75(1):89-97. 
15. Jorgensen JO, Moller N, Laruritzen T, Alberti KG, Orskov H, Christiansen JS. Evening versus morning injections of growth hormone $(\mathrm{GH})$ in $\mathrm{GH}$-deficient patients: effects on 24-hour patterns of circulating hormones and metabolites. J Clin Endocrinol Metab. 1990;70(1):207-214.

16. Kastrup KW, Christiansen JS, Andersen JK, Orskov H. Increased growth rate following transfer to daily sc administration from three weekly im injections of $\mathrm{hGH}$ in growth hormone deficient children. Acta Endocrinol (Copenh). 1983;104(2):148-152.

17. MacGillivray MH, Baptista J, Johanson AJ. Outcome of a fouryear randomized study of daily versus three times weekly somatropin treatment in prepubertal naive growth hormone-deficient children. Genentech Study Group. J Clin Endocrinol Metab. 1996;91(5):1806-1809.

18. Finkelstein BS, Imperiale TF, Speroff T, Marrero U, Radcliffe DJ, Cutler L. Effect of growth hormone therapy on height in children with idiopathic short stature: a meta-analysis. Arch Pediatr Adolesc Med. 2002;156(3):230-240.

19. Bramswig JH, Fasse M, Holthoff ML, von Lengerke HJ, von Petrykowski W, Schellong G. Adult height in boys and girls with untreated short stature and constitutional delay of growth and puberty: accuracy of five different methods of height predicition. J Pediatr. 1990;11(7):886-891.

20. Hardin DS, Woo J, Butsch R, Huett B. Current prescribing practices and opinions about growth hormone therapy: results of a nationwide survey of paediatric endocrinologists. Clin Endocrinol (Oxf). 2007;66(1):85-94.

21. Voss LD. Growth hormone therapy for the short normal child: who needs it and who wants it. J Pediatr. 2000;136(1):103-106.

22. Saenger P. The case in support of GH therapy. J Pediatr. 2000;136(1): 106-109.

23. American Academy of Pediatrics Committee on Drugs and Committee on Bioethics. Considerations related to the use of recombinant human growth hormone in children. Pediatrics. 1997;99(1): 122-129.

24. Kemp SF, Dana K, Frane J, Lippe B. Idiopathic Short Stature (ISS): What has changed since FDA approval of growth hormone $(\mathrm{GH})$ for this diagnosis? Data from the Genentech (GNE) National Cooperative Growth Study (NCGS). Paper presented at: Annual Meeting of The Endocrine Society, 2007; Toronto, Canada.

25. Fine RN. Recombinant human growth hormone in children with chronic renal insufficiency - clinical update: 1995. Kid Int Suppl. 1996;53:S1115-S1118.

26. Kemp SF, Kuntzie J, Attie KM, et al. Efficacy and safety results of long-term growth hormone treatment of idiopathic short stature. J Clin Endocrinol Metab. 2005;90(9):5247-5253.

27. Ranke MB, Lindberg A, Chatelain P, et al. Prediction of long-term response to recombinant human growth hormone in Turner syndrome: development and validation of mathematical models. KIGS International Board. Kabi International Growth Study. J Clin Endocrinol Metab. 2000;85(11):4212-4218.

28. Ranke MB, Lindberg A, Cowell CT, et al. Prediction of response to growth hormone treatment in short children born small for gestational age: analysis of data from KIGS (Pharmacia International Growth Database). J Clin Endocrinol Metab. 2003;88(1):125-131.

29. Root AW, Kemp SF, Rundle AC, Dana K, Attie KM. Effect of long-term recombinant growth hormone therapy in children National Cooperative Growth Study, USA, 1985-1994. J Pediatr Endocrinol Metabol. 1998;11:403-412.

30. Rekers-Mombarg LTM, Wit JM, Massa GG, et al. Spontaneous growth in idiopathic short stature. European Study Group. Arch Dis Child. 1996;75(3):175-180.

31. Leschek EW, Rose SR, Yanovski JA, et al. Effect of growth hormone treatment on adult height in peripubertal children with idiopathic short stature: a randomized, double-blind, placebo-controlled trial. J Clin Endocrinol Metab. 2004;89(7):3140-3148.
32. Wit JM, Rekers-Mombarg LTM, Cutler GB Jr, et al. Growth hormone $(\mathrm{GH})$ treatment to final height in children with idiopathic short stature: evidence for a dose effect. J Pediatr. 2005;146(1):45-53.

33. Albertsson-Wikland K, Aronson AS, Gustafsson J, et al. Dosedependent effect of growth hormone on final height in children with short stature without growth hormone deficiency. J Clin Endocrinol Metab. 2008;93(11):4342-4350.

34. Ranke MB, Lindberg A, Price DA, et al. Age at growth hormone therapy start and first-year responsiveness to growth hormone are major determinants of height outcome in idiopathic short stature. Hormone Rese. 2007;58(2):53-62.

35. Quigley CA, Gill AM, Crowe BJ, et al. Safety of growth hormone treatment in pediatric patients with idiopathic short stature. J Clin Endocrinol Metab. 2005;90(5):5188-5196.

36. Ross JL, Sandberg DE, Rose SR, et al. Psychological adaptation in children with idiopathic short stature treated with growth hormone or placebo. J Clin Endocrinol Metab. 2004;89(10):4873-4878.

37. Gordon M, Crouthamel C, Post EM, Richman RA. Psychological aspects of constitutional short stature: social competance, behavior problems, self-esteem, and family functioning. J Pediatr. 1982; 101:477-480

38. Siegal PT, Clopper RR, Stabler B. Psychological impact of significantly short stature. Acta Paediatr Scand. 1991;377 Suppl:14-18.

39. Stabler B, Clopper RR, Siegal PT, Stoppani C, Compton PG, Underwood LE. Academic achievement and psychological adjustment in short children: The National Cooperative Growth Study. J Dev Behav Pediatr. 1994;15:1-6.

40. Steinhausen HC, Dorr HG, Kannenberg R, Malin Z. The behavior profile of children and adolescents with short stature. J Dev Behav Pediatr. 2000;21:423-428.

41. Downie AB, Mulligan J, Stratford RJ, Betts PR, Voss LD. Are short normal children at a disadvantage? The Wessex growth study. BMJ. 1997;314(7074):97-100.

42. Skuse D, Gilmour J, Tian CS, Hindmarsh PC. Psychological assessment of children with short stature: a preliminary report. Acta Paediatr Scand. 1994;406 Suppl:11-16.

43. Voss LD. Short normal stature and psychological disadvantage: a critical review of the evidence. J Pediatr Endocrinol Metab. 2001; 14:701-711.

44. Voss LD, Bailey BJ, Mulligan J, Wilkin TJ, Betts PR. Short stature and school performance--the Wessex growth study. Acta Paediatr Scand. 1991;377 Suppl:29-31.

45. Kranzler JH, Rosenbloom AL, Proctor B, Diamond FB. Is short stature a handicap? A comparison of the psychosocial functioning of referred and nonreferred children with normal short stature and children with normal stature. J Pediatr. 2000;136(1):96-102.

46. Stabler B. Growth hormone insufficiency during childhood has implications for later life. Acta Paediatr Scand. 1991;377 Suppl:9-13.

47. Underwood LE. The social cost of being short: societal perceptions and biases. Acta Paediatr Scand. 1991;377 Suppl:308.

48. Sandberg DE, Bukowski WM, Fung CM, Noll RB. Height and social adjustment: are extremes a cause for concern and action? Pediatrics. 2004;114(3):744-750.

49. Balen HV-v, Sinnema G, Geenen R. Growing up with idiopathic short stature: psychosocial development and hormone treatment: a critical review. Arch Dis Child. 2006;91:433-439.

50. Kemp SF. Height and social adjustment. Pediatrics. 2005;115(2):515.

51. Cohen P, Rogol AD, Deal CL, et al. Consensus statement on the diagnosis and treatment of children with idiopathic short stature: A summary of the Growth Hormone Research Society, the Lawson Wilkins Pediatric Endocrine Society, and the European Society for Paediatric Endocrinology workshop. J Clin Endocrinol Metab. 2008;93(11):4210-4217.

52. Cosgrove C, Cohen S. Normal at Any Cost: Tall Girls, Short Boys, and the Medical Industry's Quest to Manipulate Height. New York, NY: Penguin Group; 2009. 
53. Brutt AL, Sandberg DE, John C, et al. Assessment of helth-related quality of life and patient satisfaction in children and adolescents with growth hormone deficiency or idiopathic short stature - Part 1: A critical evaluation of available tools. Hormone Rese. 2009; 72(2):65-73.

54. Bullinger M, Koltowska-Haggstrom M, Sandberg DE, et al. Healthrelated quality of life of children and adolescents with growth hormone deficiency or idiopathic short stature - Part 2: Available results and future directions. Hormone Rese. 2009;72(2):74-81.

55. Lee JM, Davis MM, Clark SJ, Hofer TP, Kemper AR. Estimated costeffectiveness of growth hormone therapy for idiopathic short stature. Arch Pediatr Adolesc Med. 2006;160(3):263-269.

56. Kemp SF. Growth hormone treatment of idiopathic short stature: history and demographic data from the NCGS. Growth Horm IGF Rese. 2005;15 Suppl A:S9-S12.

57. Savage MO. Should idiopathic short stature be treated with growth hormone? Nat Clin Pract Endocrinol Metab. 2009;5(3):148-149.

58. Woods KA, Clark AJ, Amselem S, Savage MO. Relationship between phenotype and genotype in growth hormone insensitivity syndrome. Acta Paediatr Suppl. 1999;88(428):158-162.

59. Goddard A, Dowd P, Chernausek SD, et al. Partial growth-hormone insensitivity: the role of growth-hormone receptor mutations in idiopathic short stature. J Pediatr. 1997;131 Suppl:51-55.

60. Iida K, Takahashi Y, Kaji H, et al. The C422F mutation of the growth hormone receptor gene is not responsible for short stature. J Clin Endocrinol Metab. 1999;84(11):4214-4219.

61. Savage MO, Woods KA, Johnston LB, Postel-Vinay MC, Amselem S, Clark AJ. Defects of the growth hormone receptor and their clinical implications. Growth Horm IGF Rese. 1999; 9 Suppl A:57-61.

62. Attie KM, Carlsson LM, Chen Rundle A, Sherman B. Evidence for partial growth hormone insensitivity among patients with idiopathic short stature. J Pediatr. 1995;127(2):244-250.

63. Gollust SE, Thompson RE, Gooding HC, Biesecker BB. Living with achondroplasia in an average-sized world: an assessment of quality of life. Am J Med Genet. Part A. 2003; 120(4):447-458.

64. Savage MO, Camacho-Hübner C, David A, et al. Idiopathic short stature: will genetics influence the choice between GH and IGF-1 therapy? Eur J Endocrinol. 2007;157 Suppl 1:S33-S37.

65. Rao E, Weiss B, Fukami M, et al. Pseudoautosomal deletions encompassing a novel homeobox gene cause growth failure in idiopathic short stature and Turner syndrome. Nat Genet. 1997;16(1):54-63.

66. Belin V, Cusin V, Viot G, et al. SHOX mutations in dyschondrosteosis (Leri-Weill syndrome). Nat Genet. 1998;19(1):67-69.

67. Cormier-Daire V, Belin V, Cusin V, et al. SHOX gene mutations and deletions in dyschondrosteosis or Leri-Weill syndrome. Acta Paediatr Suppl. 1999;88(433):55-59.

68. Ogata T. SHOX: pseudoautosomal homeobox containing gene for short stature and dyschondrosteosis. Growth Horm IGF Rese. 1999;9 Suppl B:53-57.

69. Binder G, Schwarze CP, Ranke MB. Identification of short stature caused by SHOX defects and therapeutic effect of recombinant human growth hormone. J Clin Endocrinol Metab. 2000;85(1):245-249.

70. Kofoed EM, Hwa V, Little B, et al. Growth hormone insensitivity associated with a STAT5b mutation. $N$ Engl J Med. 2003;349:1139-1147.

71. Domene HM, Bengolea SV, Martinez AS, et al. Deficiency of the circulating insulin-like growth factor system associated with inactivation of the acid-labile subunit. $N$ Engl J Med. 2004;350(6): 570-577.

72. Salerno M, Balestrieri B, Matrecano E, et al. Abnormal GH receptor signalling in children with idiopathic short stature. J Clin Endocrinol Metab. 2001;86:3882-3888.

73. Backeljauw PF, Underwood LE, Group TGC. Therapy for 6.5-7.5 years with recombinant insulin-like growth factor I in children wtih growth hormone insensitivity syndrome: a clinical research center study. J Clin Endocrinol Metab. 2001;86:15-14-1510.
74. Raynor K, Murphy W, Coy D, et al. Cloned SRIF receptors: identification of subtype selective peptides and demonstration of high affinity binding of linear peptides. Mole Pharmacolo. 1993; 43:838-844.

75. Camacho-Hubner C, Woods KA, Miraki-Moud F, et al. Effects of recombinant human insulin-like growth factor-I (IGF-1) therapy on the growth hormone-IGF system of a patient with a partial IGF-gene deletion. J Clin Endocrinol Metab. 1999;84:1611-1616.

76. Blethen SL, Hertz J, Kuntze J. The Increlex Growth Forum Database Registry: a Web-based patient registry for monitoring long-term safety and efficacy of Increlex treatment. Paper presented at: The Endocrine Society, 2007; Toronto, Canada.

77. Rosenbloom AL. Insulin-like growth factor-I (rhIGF-1) therapy of short stature. J Pediatr Endocrinol Metab. 2008;21:301-315.

78. Collett-Solberg PF, Misra M. The role of recombinant human insulinlike growth factor-I in treating children with short stature. $J$ Clin Endocrinol Metab. 2008;93(1):10-18.

79. Richmond EJ, Rogol AD. Recombinant human insulin-like growth factor-I therapy for children with growth disorders. Adv Ther. 2008;25(12):1276-1287.

80. Ranke MB, Wollmann HA, Savage MO. Experience with insulin-like growth factor I (IGF-1) treatment of growth hormone insensitivity syndrome (GHIS). J Pediatr Endocrinolo Metab. 1999;12:259-266.

81. Clemmons DR, Moses AC, Sommer A, et al. Rh/IGF-1/rhIGFBP-3 administration to patients with type 2 diabetes mellitus reduces insulin requirements while also lowering fasting glucose. Growth Horm IGF Rese. 2005;15(4):265-274.

82. Quattrin T, Thrailkill KM, Baker L, et al. Dual hormonal replacement with insulin and recombinant human insulin-like growth factor I in IDDM. Effects on glycemic control, IGF-1 levels, and safety profile. Diabetes Care. 1997;20(3):374-380.

83. Chernausek SD, Backeljauw PF, Frane J, Kuntze J, Underwood LE, Group GISC. Long-term treatment with recombinant insulin-like growth factor (IGF-1) in children with severe IGF-1 deficiency due to growth hormone insensitivity. J Clin Endocrinol Metab. 2007; 92(3):902-910.

84. Guevara-Aguirre J, Vasconez O, Martinez V, et al. A randomized double-blinded placebo controlled trial on safety and efficacy of recombinant human insulin-like growth factor-I in children with growth hormone deficiency. J Clin Endocrinol Metab. 1995;80: 1393-1398.

85. Midyett LK, Rogol AD, Van Meter QL, Frane J, Bright GM. Recombinant insulin-like growth factor (IGF)-I treatment in short children with low IGF-1 levels: first-year results from a randomized clinical trial. J Clin Endocrinol Metab. 2010;10(2):611-619.

86. Rosenbloom AL, Rivkees SA. Off-label use of recombinant IGF-1 to promote growth: is it appropriate? J Clin Endocrinol Metab. 2010; 95(2):505-508.

87. Wit JM, Balen HV, Kamp GA, Oostdijk W. Benefit of postponing normal puberty for improving final height. Eur J Endocrinol. 2004;151:S41-S45.

88. Kamp GA, Mul D, Waelkens JJ, et al. A randomized controlled trial of three years' growth hormone and gonadotropin-releasing hormone agonist treatment in children with idiopathic short stature and intrauterine growth retardation. J Clin Endocrinol Metab. 2001;86(7):2969-2975.

89. Pasquino AM, Pucarelli I, Roggini M, Segni M. Adult height in short normal adolescent girls treated with gonadotropin-releasing hormone analog and growth hormone. J Clin Endocrinol Metab. 2000;85(2):619-622.

90. Reiter EO. A brief review of the addition of gonadotropin-releasing hormone agonists (GnGH-ag) to growth hormone $(\mathrm{GH})$ treatment of children with idiopathic growth hormone deficiency: previously published studies from America. Molecular and Cellular Endocrinology. 2006;254-255:221-225. 
91. Magiakou MA, Manousaki D, Papadaki M, et al. The efficacy and safety of gonadotropin-releasing hormone analog treatment in childhood and adolescence: a single center, long-term follow-up study. J Clin Endocrinol Metab. 2010;95(1):109-117.

92. Hero M, Norjavaara E, Dunkel L. Inhibition of estrogen biosynthesis with a potent aromatase inhibitor increases predicted adult height in boys with idiopathic short stature: a randomized controlled trial. J Clin Endocrinol Metab. 2005;90(12):6396-6402.
93. Hero M, Wickman S, Dunkel L. Treatment with the aromatase inhibitor letrozole during adolescence increases near-final height in boys with constitutional delay of puberty. Clin Endocrinol (Oxf). 2006;64(5):510-513.

\section{Publish your work in this journal}

Biologics: Targets \& Therapy is an international, peer-reviewed journal focusing on the patho-physiological rationale for and clinical application of Biologic agents in the management of autoimmune diseases, cancers or other pathologies where a molecular target can be identified. This journal is indexed on PubMed Central, CAS, EMBase, Scopus

\section{Dovepress}

and the Elsevier Bibliographic databases. The manuscript management system is completely online and includes a very quick and fair peerreview system, which is all easy to use. Visit http://www.dovepress. com/testimonials.php to read real quotes from published authors. 